\title{
Cleaning mutualism in Santa Luzia (Cape Verde Archipelago) and São Tomé Islands, Tropical Eastern Atlantic
}

\author{
J.P. QUIMBAYO ${ }^{1,2}$, S.R. FLOETER ${ }^{1}$, R. NOGUCHI ${ }^{3}$, C.A. RANGEL ${ }^{4}$, J.L. GASPARINI ${ }^{5}$, C.L.S. SAMPAIO ${ }^{6}$, \\ C.E.L. FERREIRA ${ }^{7}$ AND L.A. ROCHA ${ }^{8}$
}

${ }^{1}$ Laboratório de Biogeografia e Macroecologia Marinha, Departamento de Ecologia e Zoologia, Centro de Ciências Biológicas, Universidade Federal de Santa Catarina, Florianópolis, SC 88010-970, Brazil, ${ }^{2}$ Grupo de investigación en ecología de arrecifes coralinos, Universidad del Valle, Apartado Aéreo 25360, Cali, Colombia, ${ }^{3}$ Universidade Federal do Rio de Janeiro, Rio de Janeiro, 21941-901, Brazil, ${ }^{4}$ Laboratório de Biologia do Nécton e Ecologia Pesqueira, Departamento de Biologia Marinha, Universidade Federal Fluminense, Niterói, RJ 24001-970, Brazil, ${ }^{5}$ Departamento de Ecologia e Recursos Naturais, Universidade Federal do Espírito Santo, Vitória, ES 29060-900, Brazil, ${ }^{6}$ Universidade Federal de Alagoas, Campus Arapiraca, Unidade de Ensino de Penedo, AL 57200-000, Brazil, 'Laboratório de Ecologia e Conservação de Ambientes Recifais, Departamento de Biologia Marinha, Universidade Federal Fluminense, Niterói, RJ 24001-970, Brazil, ${ }^{8}$ California Academy of Sciences, 55 Music Concourse Drive, San Francisco, CA 94118, USA

\begin{abstract}
This work reports for the first time cleaning activity by fish and shrimps in Santa Luzia, Cape Verde Archipelago and São Tomé Islands. Three new records of facultative cleaner fish species are presented. Facultative cleaners dominated by Labridae were the most observed cleaner fishes in the two studied islands. Multi-specific cleaning stations were prevalent in Santa Luzia, while cleaner shrimps were more observed interacting in the São Tomé Islands.
\end{abstract}

Keywords: cleaner fish, cleaner shrimp, client fish, Labridae, Africa

Submitted 16 August 2012; accepted 24 October 2012

\section{INTRDDUCTION}

Reef environments are one of the most diverse habitats in the world (Reaka-Kudla, 1997), where many intriguing ecological relationships are observed. Among those relationships, cleaning mutualism is defined as the interaction between the 'cleaner' which removes parasites, dead skin, scales and mucus from the body surface of its 'clients', which include fishes, turtles, marine iguanas, whales and octopuses (Feder, 1966; Sazima \& Moura, 2000; Grutter, 2002; Sazima et al., 2004, 2010; Floeter et al., 2007a). Cleaning is considered disproportionately important in reefs, with very few species and individuals acting as cleaners but affecting a much larger fraction of client species (Grutter et al., 2003; Floeter et al., 2007a).

According to Côté (2000), about 130 species of fish and crustaceans are known to be cleaners, the majority are facultative cleaners (organisms that rely only in small part on cleaning as a source of food), but some are obligate cleaners, which clean during their entire lifetime. Cleaning events may occur up in the water column or close to the substratum (Darcy et al., 1974). Frequently, these interactions happen in fixed sites, such as massive coral colonies, sponges or large rock formations called 'cleaning stations' (Feder, 1966; Losey, 1974; Côté, 2000; White et al., 2007), which can be

Corresponding author:

J.P. Quimbayo

Email: jupaquia@gmail.com occupied by a variable number of individuals from one or more species of cleaners (Johnson \& Ruben, 1988; Wicksten, 1998).

Cleaning stations are described as an important factor affecting the small-scale distribution and density of fish populations on a given reef, because clients tend to aggregate at or near cleaning stations searching for the cleaner's 'services' (Slobodkin \& Fishelson, 1974; Grutter et al., 2002, 2003; Whiteman \& Côté, 2002; Waldie et al., 2011).

Cleaning interactions are well studied in many places in the Indo-Pacific (e.g. Grutter \& Poulin, 1998; Côté, 2000), Caribbean (e.g. Johnson \& Ruben, 1988; Arnal et al., 2000, Côté, 2000) and south-western Atlantic (e.g. Sazima et al., 1998, 1999, 2000; Francini-Filho et al., 2000; Sazima \& Sazima, 2001; Gasparini et al., 2008; Coni et al., 2011). However, little is known about cleaning mutualism in the Tropical Eastern Atlantic. This study is the first to address the diversity of reef fish clients and cleaners, and the frequency of interactions in two oceanic islands from the Tropical Eastern Atlantic: Santa Luzia Island in the Cape Verde Archipelago and São Tomé Island. We also present the first records of three cleaner fish species and cleaner shrimps for this region.

\section{MATERIALS AND METHDDS}

Fieldwork was carried out in the island of São Tomé $\left(0^{\circ} \mathrm{oo}^{\prime} \mathrm{N}\right.$ $7^{\circ} 24^{\prime} \mathrm{W}$; located $\sim 250 \mathrm{~km}$ off the African coast) in February 
2006 summing up $\sim 135$ hours of underwater activities and the island of Santa Luzia (Cape Verde Archipelago; $16^{\circ} 45^{\prime} \mathrm{N}$ $24^{\circ} 23^{\prime} \mathrm{W}, \sim 560 \mathrm{~km}$ off the African coast) in September 2009 summing up $\sim 60$ hours of underwater activities.

These islands are characterized by volcanic rocky reefs with the presence of sparce hard corals. All the work was conducted from 10:00 to 16 :00 $\mathrm{h}$ in relatively shallow waters at 3 to $20 \mathrm{~m}$ depth. Replicated underwater visual censuses $(\mathrm{N}=198)$ of $20 \times 2 \mathrm{~m}$ (see Floeter et al., 2007b for details of the method) were used to assess the reef fish community at Santa Luzia Island.

Cleaning associations were recorded from direct observations, and digital images and videos obtained during two expeditions aimed at documenting the marine biota from both islands. All instances of cleaning observed were recorded at stations or in the water column, but only a fraction of the time spent underwater was used for this, so calculation of the cleaning rate per unit time was not possible.

\section{RESULTS}

\section{Santa Luzia Island, Cape Verde Archipelago}

Four fish species were recorded as cleaners in Santa Luzia Island (Table 1). Two of them were responsible for almost all ( 91\%) interactions (Table 1): Bodianus speciosus (52\% of cleaning events) (Figures $1 \mathrm{~A} \& 2 \mathrm{~A}, \mathrm{~B}, \mathrm{C}$ ), and Coris atlantica $(39 \%)$, the latter recorded as a cleaner for the first time (Figure 2A). Bodianus speciosus and C. atlantica were found together tending multi-specific cleaning stations in eight out of 12 observations. Bodianus speciosus was recorded cleaning alone on three occasions (25\%), and C. atlantica was never observed cleaning without $B$. speciosus in the same station. Thalassoma pavo (6\%) (Figure 1A, B) and Canthisgaster capistrata $(3 \%$; also recorded as a cleaner for the first time, Figure $1 \mathrm{~A}$ ) were recorded in only $9 \%$ of all events, and always in multi-specific stations. Each cleaning station ocuppied an area around 2 to $4 \mathrm{~m}^{2}$, with clients posing to solicit inspection. Sparisoma cretense usually laid down in the reef to elicit cleaning (Figure $1 \mathrm{~A}, \mathrm{~B}$ ). In $8 \%$ of the encounters, the clients initiated the cleaning event, and in half of the events clients changed colour to bring attention of the cleaners. Clients were inspected in all body parts, but in many instances cleaners concentrated around the gills (Figures $1 \mathrm{~A} \& 2 \mathrm{C}$ ).

Sixty-seven reef fish species were recorded as potential clients but only 13 species in eight families were recorded as clients in Santa Luzia (Table 1). Six of these (Chelon bispinosus, Diodon holocanthus, Diplodus prayensis, Mulloidichthys martinicus, Pseudupeneus prayensis and Scarus hoefleri) were recorded interacting only once $\left(<_{1} \%\right)$, what may be considered an indication of the low frequency of such events. We

Table 1. Number and proportion of cleaning events involving clients with more than one recorded interaction in the island of Santa Luzia, Cape Verde Archipelago. Families are disposed alphabetically. Taxonomy follows that of Nelson (2006) except for Epinephelidae (Craig et al., 2011) and Labridae (Cowman et al., 2009).

\begin{tabular}{|c|c|c|c|c|c|c|c|}
\hline \multirow[t]{2}{*}{ Clients species } & \multicolumn{4}{|l|}{ Cleaners } & \multirow[t]{2}{*}{ Total } & \multirow[t]{2}{*}{$\%$} & \multirow{2}{*}{$\begin{array}{l}\text { Multi-specific } \\
\text { station }\end{array}$} \\
\hline & $\begin{array}{l}\text { Bodianus } \\
\text { speciosus } \\
\text { (a) }\end{array}$ & $\begin{array}{l}\text { Coris } \\
\text { atlantica** } \\
\text { (b) }\end{array}$ & $\begin{array}{l}\text { Thalassoma } \\
\text { pavo } \\
\text { (c) }\end{array}$ & $\begin{array}{l}\text { Canthigaster } \\
\text { capistrata** } \\
\text { (d) }\end{array}$ & & & \\
\hline \multicolumn{8}{|l|}{ Acanthuridae } \\
\hline Acanthurus monroviae & 4 & 2 & & & 6 & 5.71 & $a, b$ \\
\hline \multicolumn{8}{|l|}{ Epinephelidae } \\
\hline Cephalopholis taeniops & 2 & 1 & & 1 & 4 & 3.80 & $\mathrm{a}, \mathrm{b}$ \\
\hline \multicolumn{8}{|l|}{ Labridae } \\
\hline Bodianus speciosus & 4 & 1 & & & 5 & 4.76 & \\
\hline Thalassoma pavo & 2 & & & & 2 & 1.90 & \\
\hline Scarus hoefleri* & & 1 & & & 1 & 0.95 & \\
\hline Sparisoma cretense & 16 & 3 & 1 & 1 & 21 & 20.0 & $\mathrm{a}, \mathrm{b}, \mathrm{c}, \mathrm{d}$ \\
\hline \multicolumn{8}{|l|}{ Mugilidae } \\
\hline Chelon bispinosus* & 1 & & & & 1 & 0.95 & \\
\hline \multicolumn{8}{|l|}{ Mullidae } \\
\hline Pseudopneus prayensis* & 1 & & & & 1 & 0.95 & \\
\hline Mulloidichthys martinicus* & 1 & & & 1 & 2 & 1.90 & \\
\hline \multicolumn{8}{|l|}{ Pomacentridae } \\
\hline Chromis lubbocki & 10 & 24 & 3 & & 37 & 35.23 & $\mathrm{a}, \mathrm{b}$ \\
\hline Chromis multilineata & 12 & 9 & 2 & & 23 & 21.90 & $\mathrm{a}, \mathrm{b}$ \\
\hline \multicolumn{8}{|l|}{ Sparidae } \\
\hline Diplodus prayensis & 1 & & & & 1 & 0.95 & \\
\hline \multicolumn{8}{|l|}{ Tetraodontidae } \\
\hline Diodon holocanthus* & 1 & & & & 1 & 0.95 & \\
\hline Total number of events & 55 & 41 & 6 & 3 & 105 & & \\
\hline percentage & 52.45 & 39.0 & 5.71 & 2.84 & 100 & & \\
\hline Number of species per & 7 & 6 & 3 & 2 & 7 & & \\
\hline \multicolumn{8}{|l|}{ host } \\
\hline Density $4 \mathrm{om}^{2}$ & 1.04 & 4.16 & 27.8 & 1.19 & & & \\
\hline
\end{tabular}

*, species recorded in only one event; ${ }^{*}$, new record of facultative cleaner. 


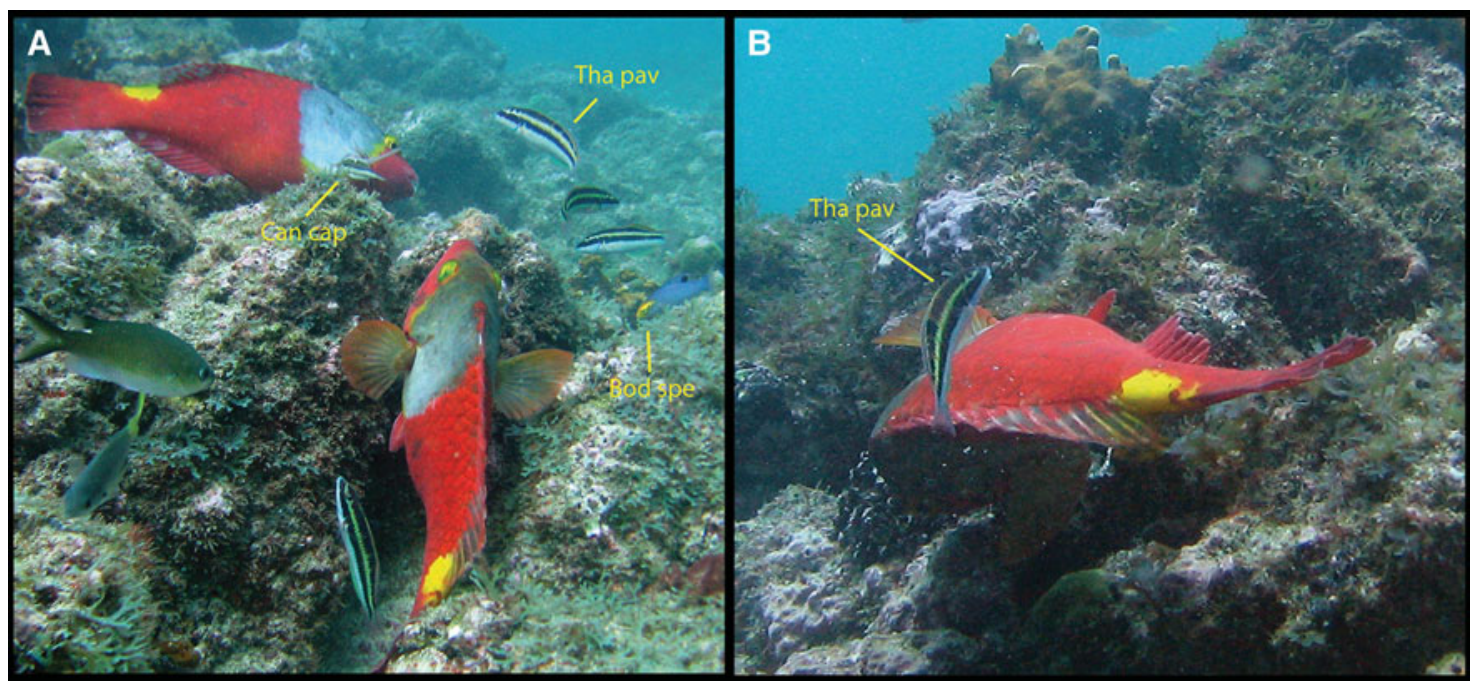

Fig. 1. Cleaning interactions at a multi-specific cleaning station at about $10 \mathrm{~m}$ deep in Santa Luzia Island, Cape Verde Archipelago, September 2009: (A) Bodianus speciosus, Canthigaster capistrata and Thalassoma pavo cleaning two Sparisoma cretense; (B) T. pavo interacting with S. cretense laying down to solicit inspection.

observed 98 cleaning events for the remaining seven species. The most common clients were of the genera Chromis (Pomacentridae, $57.1 \%$ of cleaning events) and Sparisoma (Labridae, 27.6\%) (Table 1).

\section{São Tomé Island}

Six fishes and two crustaceans were recorded as cleaners in São Tomé Island (Table 2). The shrimp Lysmata spp. had most

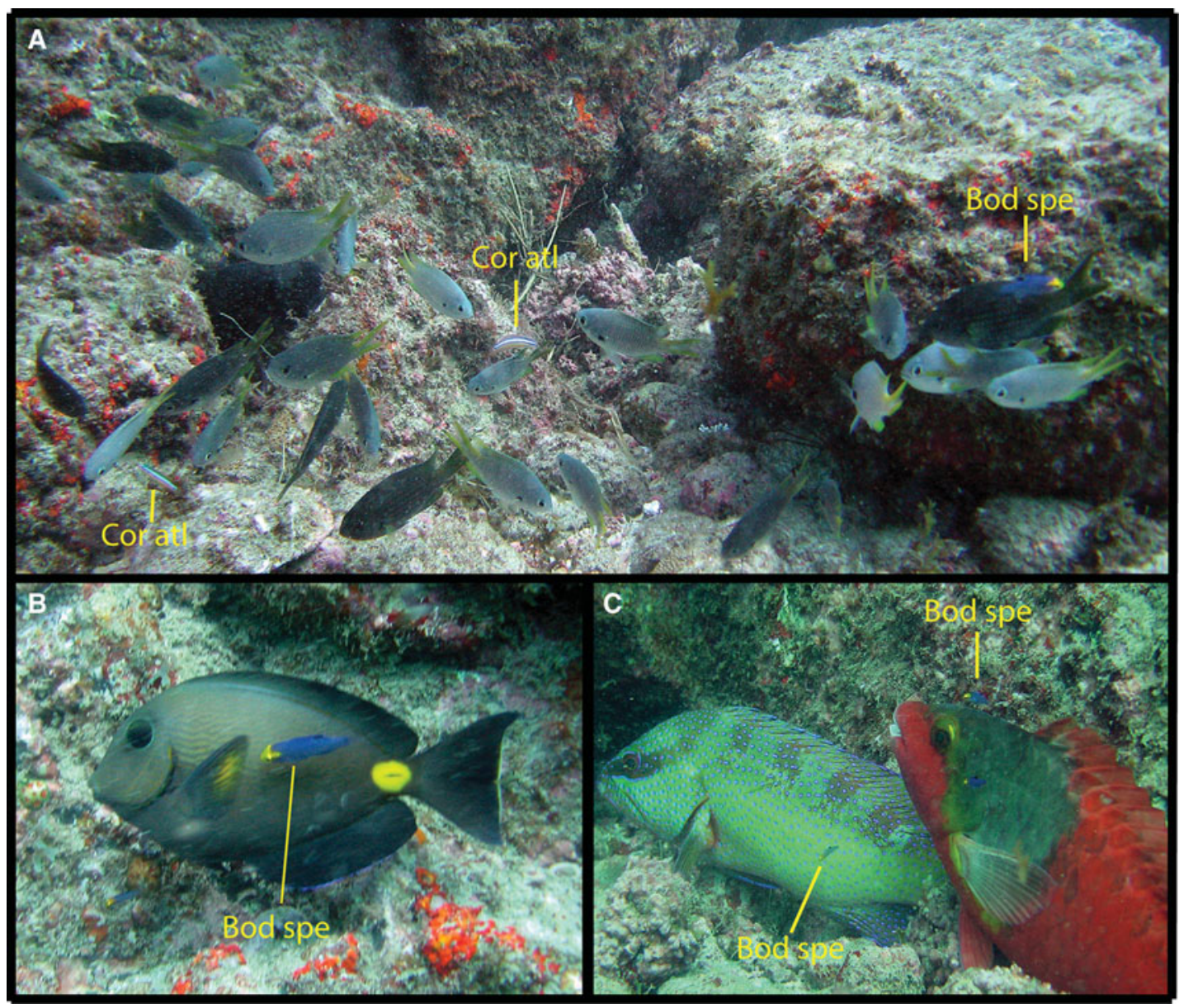

Fig. 2. Cleaning interactions at a multi-specific cleaning station from 6 to $10 \mathrm{~m}$ deep in Santa Luzia Island, Cape Verde Archipelago, September 2009: (A) Bodianus speciosus and Coris atlantica cleaning client species Chromis lubbocki and C. multilineata; (B) B. speciosus cleaning Acanthurus monroviae; (C) B. speciosus cleaning Cephalopholis taeniops and Sparisoma cretense. 


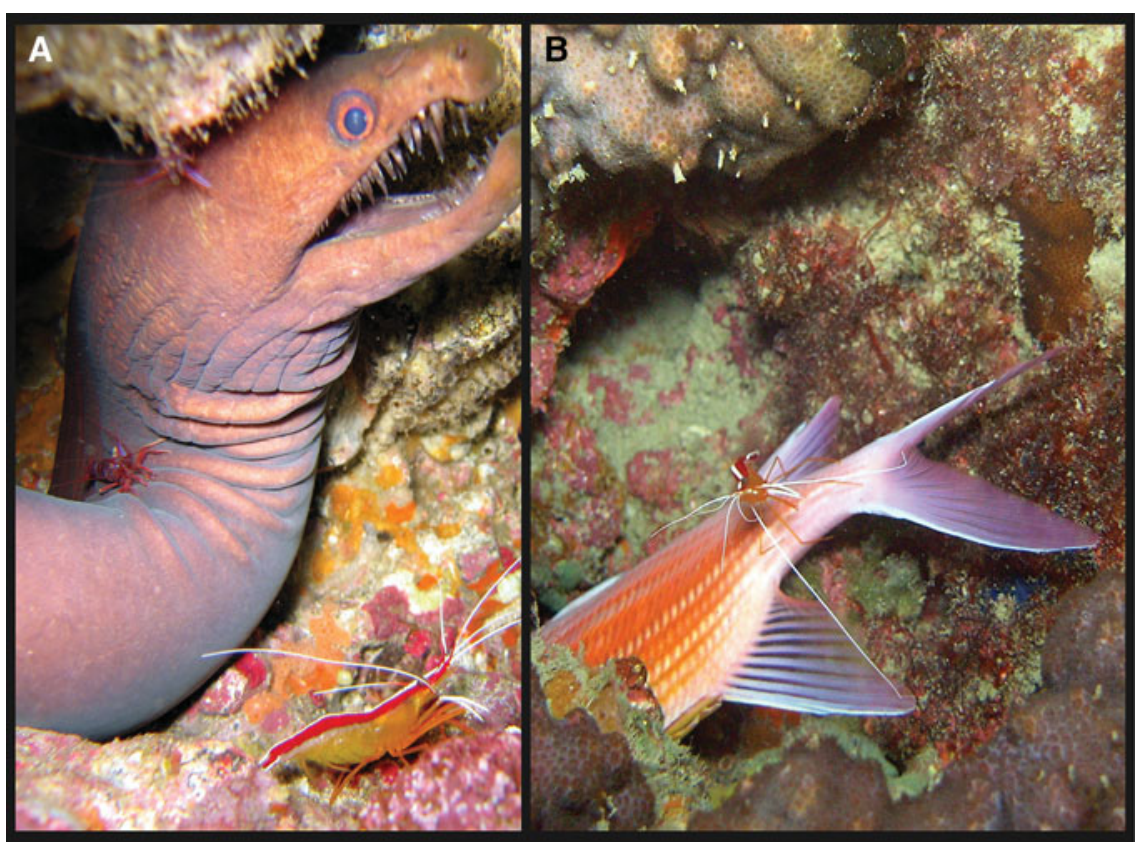

Fig. 3. Cleaning by shrimps under a reef structure at about $12 \mathrm{~m}$ deep in São Tomé Island, February 2006: (A) Lysmata spp. cleaning Enchelycore nigricans; (B) Lysmata grabhami interacting with Sargocentron hastatum.

clients, eight ( $38 \%$ of all clients) from three families of fish and one crustacean (Figure 3A, B). The wrasse Bodianus speciosus, had six clients $(23 \%$ of all clients) from five families (Figure ${ }_{4} \mathrm{~B}$ ), while B. pulchellus had three fish clients (Figure $4 \mathrm{C}$ ). Other than the two Bodianus, two other species of the family Labridae were observed in cleaning activities: Coris atlantica and Thalassoma newtoni. In total, cleaner fishes of the family Labridae were observed cleaning $50 \%$ of all client species. Differently from Santa Luzia, no multi-specific cleaning stations were found in São Tomé. From the 66 species of reef fish observed during this expedition, a total of 16 (from 11 different families) were recorded as clients, as well as the green turtle C. mydas (Table 2).

We also report for the first time 'facultative' cleaning behaviour by the eastern Atlantic endemic butterflyfish (Chaetodontidae) Chaetodon robustus. It was observed cleaning the creole fish Paranthias furcifer and the goatfish Mulloidichthys martinicus (Figure 4A).

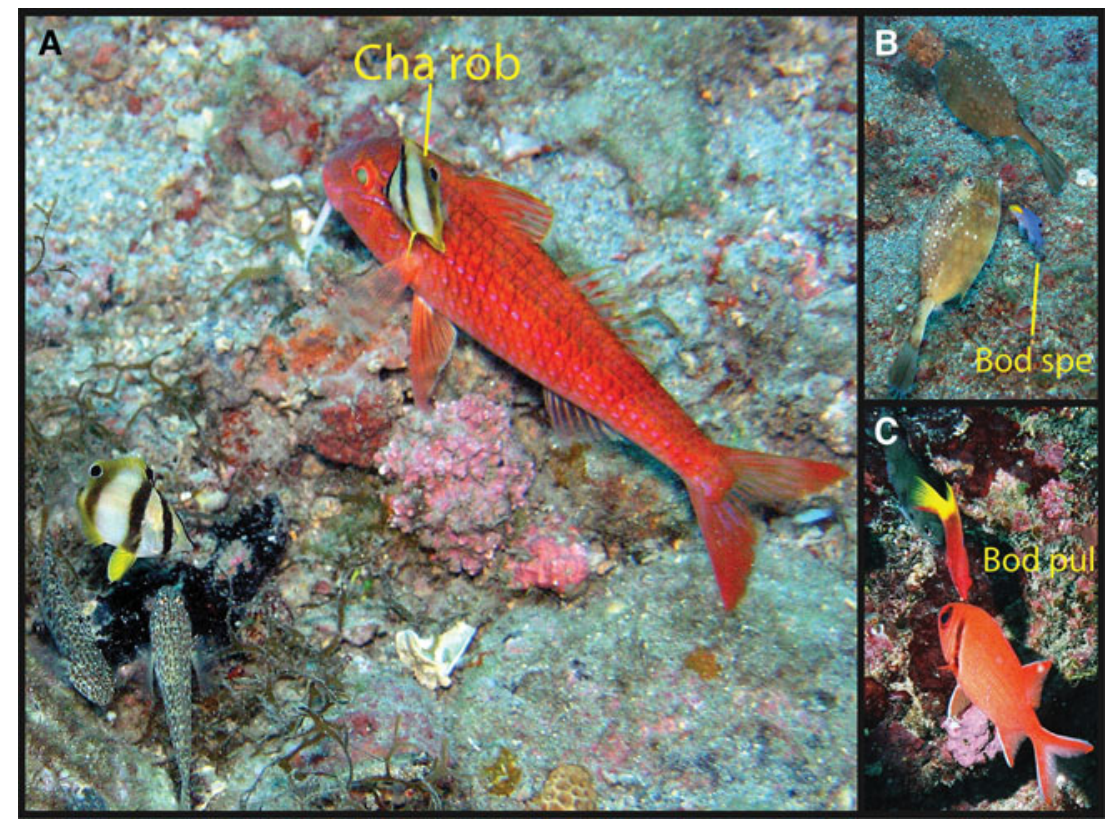

Fig. 4. Cleaning activity by fishes over rodolith beds at about $15 \mathrm{~m}$ deep in São Tomé Island, February 2006: (A) new record of the cleaner Chaetodon robustus, interacting with Mulloidichthys martinicus changing its predominant colour pattern; (B) Bodianus speciosus cleaning Acanthostracion notacanthus; (C) Bodianus pulchellus interacting with Myripristis jacobus. 
Table 2. Marine species reported as cleaners and clients in the islands of São Tomé and Príncipe.

\begin{tabular}{|c|c|c|}
\hline Cleaners & Clients & Reference \\
\hline \multicolumn{3}{|l|}{ FISHES } \\
\hline \multicolumn{3}{|l|}{ Chaetodontidae } \\
\hline \multirow{2}{*}{$\begin{array}{l}\text { Chaetodon } \\
\text { robustus* }\end{array}$} & Paranthias furcifer & Present paper \\
\hline & $\begin{array}{l}\text { Mulloidichthys } \\
\text { martinicus }\end{array}$ & Present paper \\
\hline \multicolumn{3}{|l|}{ Labridae } \\
\hline \multirow[t]{4}{*}{$\begin{array}{l}\text { Bodianus } \\
\quad \text { pulchellus }\end{array}$} & Clepticus africanus & $\begin{array}{l}\text { Afonso et al., 1999; present } \\
\text { paper }\end{array}$ \\
\hline & Myripristis jacobus & Present paper \\
\hline & $\begin{array}{l}\text { Paranthias furcifer } \\
\text { Turtle }\end{array}$ & Present paper \\
\hline & Chelonia mydas & Wirtz et al., 2007 \\
\hline \multirow[t]{6}{*}{ Bodianus speciosus } & Acanthurus monroviae & Afonso et al., 1999 \\
\hline & Apsilus fuscus & Afonso et al., 1999 \\
\hline & Paranthias furcifer & Present paper \\
\hline & Chaetodon robustus & Afonso et al., 1999 \\
\hline & Lutjanus goereensis & Debelius, 1997 \\
\hline & $\begin{array}{l}\text { Acanthostracion } \\
\text { notacanthus }\end{array}$ & Present paper \\
\hline \multirow[t]{2}{*}{ Coris atlantica* } & Acanthurus monroviae & Present paper \\
\hline & Paranthias furcifer & Present paper \\
\hline $\begin{array}{c}\text { Thalassoma } \\
\text { newtoni }\end{array}$ & Acanthurus monroviae & Present paper \\
\hline \multicolumn{3}{|l|}{ Pomacentridae } \\
\hline Abudefduf taurus & Acanthurus monroviae & $\begin{array}{l}\text { Wirtz et al., 2007; present } \\
\text { paper }\end{array}$ \\
\hline \multicolumn{3}{|l|}{ CRUSTACEANS } \\
\hline \multicolumn{3}{|l|}{ Hyppolytidae } \\
\hline \multirow[t]{9}{*}{ Lysmata grabhami } & Acanthurus monroviae & $\begin{array}{l}\text { Wirtz, 2003, 2004; present } \\
\text { paper }\end{array}$ \\
\hline & Paranthias furcifer & Present paper \\
\hline & Chromis multilineata & Present paper \\
\hline & Enchelycore nigricans & Present paper \\
\hline & Echidna peli & Present paper \\
\hline & Muraena melanotis & Present paper \\
\hline & Holocentrus adscensionis & Present paper \\
\hline & Myripristis jacobus & Present paper \\
\hline & Sargocentron hastatum & Present paper \\
\hline Lysmata spp. & Enchelycore nigricans & Present paper \\
\hline
\end{tabular}

*, new record of facultative cleaner.

\section{DISCUSSION}

According to Côté (2000) all eight cleaner species found in the present study are considered facultative cleaners (i.e. species that do not rely on cleaning activities as a substantial part of their diets). The lack of specialized cleaner fishes (i.e. Elacatinus spp. and Labroides spp.) in the Tropical Eastern Atlantic is intriguing and is most probably related to biogeography and evolution of these lineages, restricted to richer coral reef regions. The most observed cleaner fishes in both islands are the labrids Bodianus, Coris and Thalassoma.

In Santa Luzia, we observed an atypically high occurrence of multi-specific cleaning stations (more than half of the stations). Despite reports of mixed stations in the western Atlantic (e.g. Elacatinus evelynae and juveniles of Bodianus rufus by Johnson \& Ruber (1988) for the Caribbean, and Elacatinus figaro and juveniles of Pomacanthus paru in Abrolhos reef, Brazil by Sazima et al. (2000)), in many reefs around the world, multi-specific cleaning stations are not that common (e.g. less than $10 \%$ of the stations are multispecific in most reef areas in Brazil, in the west Pacific and in the Tropical Eastern Pacific; authors, personal observations).

The important functional role of the obligate (Côté, 2000) cleaner shrimps of the genus Lysmata spp. is evident in São Tomé. These species were involved in $56 \%$ of all reported clients (Table 2). Interestingly, only four species of clients $(\sim 25 \%)$ were shared between fish and shrimps (Acanthurus monroviae, Paranthias furcifer, Chromis multilineata and Myripristis jacobus). Moreover, moray eels were clients exclusively of shrimps, as both prefer to live in refuge holes in the reef, which facilitates the interaction. The other two client species were Holocentrus adscensionis and Sargocentron hastatum which are predominantly nocturnal, but also stay in or close to refuge holes during the day. This behaviour may facilitate the interaction between the clients and the shrimps.

Cleaners of the family Labridae (wrasses) are important in the studied sites, responsible for cleaning of all the client species in Cape Verde and half of the clients in São Tomé. The wrasse Bodianus speciosus is the most important cleaner fish in both islands and may be playing a similar role in the Tropical Eastern Atlantic as its western Atlantic congener B. rufus in the Caribbean and Tropical South-Western Atlantic (Johnson \& Ruben, 1988; Feitoza \& Correia, 2003; Sazima et al., 2010; Coni et al., 2011). Cleaning events by Bodianus pulchellus are rarely observed because this species prefers deeper parts of the reef (Sazima et al., 2010). In São Tomé, B. pulchellus was found cleaning in shallow waters $(5$ to $15 \mathrm{~m}$ deep), as also noted by Luiz et al. (2008) on the southeastern coast of Brazil.

Coris atlantica was the second most important cleaner in Santa Luzia, and was seen in large cleaning stations (Figure 5) in São Tomé. This new record adds to the list of facultative cleaners of the genus Coris. Its sister-species, Coris julis is reported to be a cleaner in the Mediterranean Sea (Zander \& Sötje, 2002) and in the Azores islands (Bertoncini et al., 2009). Cleaners of the genus Thalassoma have been traditionally considered as common cleaners that interact with a broad number of clients in reef environments (Johnson \& Ruben, 1988). Thalassoma pavo and T. newtoni, however, were observed interacting in relatively low

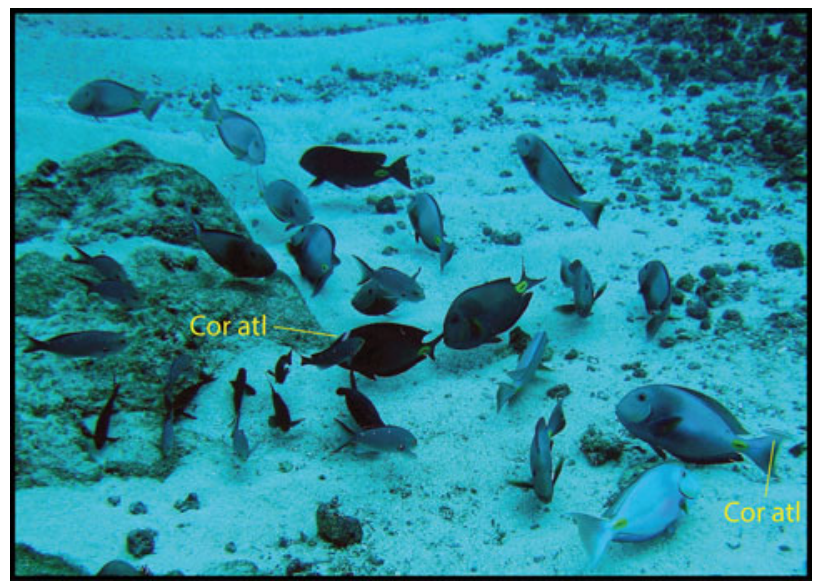

Fig. 5. Cleaning station tended by Coris atlantica in a sand patch at about $18 \mathrm{~m}$ deep, involving clients Acanthurus monroviae and Paranthias furcifer changing colour while being cleaned or inspected (São Tomé Island, February 2006). 
frequency, differently from other species of the genus Thalassoma in the western Atlantic (Johnson \& Ruben, 1988; Francini-Filho et al., 2000; Sazima et al., 2005).

The new record of Canthisgaster capistrata in Santa Luzia as a facultative cleaner adds to the list of cleaners of the genus Canthisgaster. Previously, only two other species from this genus were recorded (Côté, 2000).

The Pomacentridae Abudefduf taurus was an occasional cleaner in São Tomé (Wirtz et al., 2007). This behaviour has been observed in its congener A. troschelii from the Tropical Eastern Pacific (McCourt \& Thomson, 1984). Abudefduf saxatilis (juvenile) is recorded as occasional cleaner in the western Atlantic (Whiteman et al., 2002), but was not observed cleaning in the studied islands.

Floeter et al. (2007a) found a strong correlation between abundance of a given fish in an assemblage and its tendency to be cleaned. In Santa Luzia, the high frequency of cleaning events involving Chromis as a client may be due to its high abundance ( $48 \%$ of all individuals counted in visual censuses are Chromis). Moreover, in São Tomé, the highly abundant Paranthias furcifer was cleaned by five out of eight observed cleaners, thus indicating the same trend. Quantitative data in the understudied Tropical Eastern Atlantic are needed for a comprehensive understanding of the role of cleaning mutualism in a relatively species-poor region that lacks obligate cleaners.

\section{ACKNDWLEDGEMENTS}

We thank CNPq Pro-Africa for grant No. 490531/2007-5 to C.E.L.F. (PI) to work in Cape Verde and the National Geographic Society for research grant No. 7937-05 to S.R.F. (PI) to work in São Tomé. We are greatful to the staff from Universidade de Cabo Verde for support and guidance in the field, everyone at Direcção de Pescas de São Tomé e Príncipe and Angus Gascoigne (in memoriam) for permits and logistics, Jean Louis and all the crew of 'Club Maxell', Nacho from Gandu Diving, Nora Rizzo, Flavia Nunes, Nancy Knowlton, and the people of Cabo Verde and São Tomé e Príncipe for wonderful times. We also thank Peter Wirtz and Osmar Luiz for comments on earlier drafts.

\section{REFERENCES}

Afonso P., Porteiro F.M., Santos R.S., Barreiros J.P., Worms J. and Wirtz P. (1999) Coastal marine fishes of São Tomé Island (Gulf of Guinea). Arquipélago: Life and Marine Sciences 17A, 65-92.

Arnal C., Côté I.M., Sasal P. and Morand S. (2000) Cleaner-client interactions on a Caribbean reef: influence of correlates of parasitism. Behavioral Ecology and Sociobiology 47, 353-358.

Bertoncini A.A., Machado L.F., Barreiros J.P., Hostim-Silva M. and Verani J.R. (2009) Cleaning activity among Labridae in the Azores: the rainbow wrasse Coris julis and the Azorean blue wrasse Centrolabrus caeruleus. Journal of the Marine Biological Association of the United Kingdom 89, 859-861.

Coni E.O.C., Nunes J.A.C.C., Ferreira C.M., Maia-Nogueira R., Medeiros D.V. and Sampaio C.L.S. (2011) The Spanish hogfish Bodianus rufus (Labridae) acting as cleaner of nocturnal fish in the north-east of Brazil. Marine Biodiversity Records 3, e23. DOI: http:// dx.doi.org/10.1017/S1755267210000187.
Côté I.M. (2000) Evolution and ecology of cleaning symbiosis in the sea. Oceanography and Marine Biology: an Annual Review 38, 311-355.

Cowman P.F., Bellwood D.R. and van Herwerden L. (2009) Dating the evolutionary origins of wrasse lineages (Labridae) and the rise of trophic novelty on coral reefs. Molecular Phylogenetics and Evolution $52,621-631$.

Craig M.T., Sadovy de Mitcheson Y.J. and Heemstra P.C. (2011) Groupers of the world: a field and market guide. Grahamstown, South Africa: NISC (Pty) Ltd.

Darcy G.H., Maisel E. and Ogden T.C. (1974) Cleaning preferences of the gobies Gobiossoma evelynae and G. prochilos and the juvenile wrasse Thalassoma bifasciatum. Copeia 1974, 375-379.

Debelius H. (1997) Mediterranean and Atlantic fish guide. 1st edition. Frankfurt, Germany: IKAN-Unterwasserarchiv.

Feder H.M. (1966) Cleaning symbiosis in the marine environment. In Henry S.M. (ed.) Symbiosis. Volume 1. New York: Academic Press, pp. $327-380$.

Feitoza C.V. and Correia L.B. (2003) Cleaning activity of Bodianus rufus on Clepticus brasiliensis (Actinopterygii-Perciformes). Coral Reefs 22, 10 .

Floeter S.R., Vázquez D.P. and Grutter A.S. (2007a) The macroecology of marine cleaning mutualisms. Journal of Animal Ecology 76, 105-111.

Floeter S.R., Krohling W., Gasparini J.L., Ferreira C.E.L. and Zalmon I. (2007b) Reef fish community structure on coastal islands of the southeastern Brazil: the influence of exposure and benthic cover. Environmental Biology of Fishes 78, 147-160.

Fracini-Filho R.B., Moura R.L. and Sazima I. (2000) Cleaning by the wrasse Thalassoma noronhamun, with two records of predation by its grouper client Cephalopholis fulva. Journal of Fish Biology 56, $802-809$.

Gasparini J.L., Luiz Jr O.J. and Sazima I. (2008) Cleaners from the underground. Coral Reefs 27, 143.

Grutter A.S. and Poulin R. (1998) Cleaning on coral reefs by the wrasse Labroides dimidiatus: influence of client body size and phylogeny. Copeia 1, 120-127.

Grutter A.S. (2002) Cleaning symbioses from the parasites' perspective. Parasitology 124, S65-S81.

Grutter A.S., McCallum H. and Lester R.J.G. (2002) Optimising cleaning behaviour: minimising the costs and maximising ectoparasite removal. Marine Ecology Progress Series 234, 257-264.

Grutter A.S., Murphy J.M. and Choat J.H. (2003) Cleaner fish drives local fish diversity on coral reefs. Current Biology 13, 64-67.

Johnson W.S. and Ruben P. (1988) Cleaning behaviour of Bodianus rufus, Thalassoma bifasciatum, Gobiosoma evelynae, and Periclimenes pedersoni along a depth gradient at Salt River submarine canyon, St. Croix. Environmental Biology of Fishes 23, 225-232.

Losey G.S. (1974) Cleaning symbiosis in Puerto Rico with comparison to the Tropical Pacific. Copeia 4, 960-970.

Luiz O.J., Carvalho-Filho A., Ferreira C.F.L, Floeter S.R., Gasparini J.I. and Sazima I. (2008) The reef fish assemblage of the Laje de Santos Marine State Park, Southwestern Atlantic: annotated ckecklist with comments on abundance, distibution, trophic structure, symbiotic association, and conservation. Zootaxa 1807, 1-25.

McCourt R.M. and Thomson D.A. (1984) Cleaning behaviour of the juvenile Panamic sergeant major, Abudefduf troschelii (Gill), with a résumé of cleaning associations in the Gulf of California and adjacent waters. California Fish and Game 70, 234-239. 
Nelson J.S. (2006) Fishes of the world. 4th edition. New York: John Wiley and Sons.

Reaka-Kudla M.L. (1997) The global biodiversity of coral reefs: a comparison with rain forests. In Reaka-Kudla M.L., Wilson D.E. and Wilson E.O. (eds) Biodiversity II: understanding and protecting our biological resources. Washington, DC: Joseph Henry Press, pp. 83108.

Sazima I., Gasparini J.L. and Moura R.L. (1998) The wrasse Halichoeres cyanocephalus (Labridae) as a specialized cleaner. Bulletin of Marine Science 63, 605-610.

Sazima I., Moura R.L. and Sazima C. (1999) Cleaning activity of juvenile angelfish, Pomacanthus paru, on the reefs of the Abrolhos Archipelago, western South Atlantic. Environmental Biology of Fishes 56, 399-407.

Sazima I. and Moura R.L. (2000) Shark (Carcharhinus perezi), cleaned by the goby (Elacatinus randalli), at Fernando de Noronha Archipelago, Western South Atlantic. Copeia 2000, 297-299.

Sazima I., Sazima C., Francini-Filho R.B. and Moura R. (2000) Daily cleaning activity and diversity of clients of the barber goby, Elacatinus figaro, on rocky reefs in south-eastern Brazil. Environmental Biology of Fishes 59, 66-77.

Sazima C. and Sazima I. (2001) Plankton-feeding aggregation and occasional cleaning by adult butterflyfish, Chaetodon striatus (Chaetodontidae), in south-western Atlantic. Cybium 25, 145-151.

Sazima I., Krajewski J.P., Bonaldo R.M. and Sazima C. (2004) Octopus cleaned by two fish species at Fernando de Noronha Archipelago, SW Atlantic. Coral Reefs 23, 484.

Sazima C., Krajewski J.P., Bonaldo R.M. and Sazima I. (2005) The glassy sweepers' way: seeking a versatile wrasse to be cleaned. Neotropical Ichthyology 3, 119-122.

Sazima I., Grosman A. and Sazima C. (2010) Deep cleaning: a wrasse and a goby clean reef fish below $60 \mathrm{~m}$ depth in the tropical south-western Atlantic. Marine Biodiversity Records 3, e6o. DOI: http://dx.doi.org/10. 1017/S1755267210000497.

Slobodkin L.B. and Fishelson L. (1974) The effect of the cleaner fish Labroides dimidiatus on the pount diversity of fishes on the reef front at Eilat. American Naturalist 108, 369-376.
Waldie P.A., Blomberg S.P., Cheney K.L., Goldizen A.W. and Grutter A.S. (2011) Long-term effects of the cleaner fish on Labroides dimidiatus on coral reef communities. PlosOne 6, 1-7.

White J.W., Grigsby C.J. and Warner R.R. (2007) Cleaning behavior is riskier and less profitable than an alternative strategy for a facultative cleaner fish. Coral Reefs 26, 87-94.

Whiteman E.A. and Côté I.M. (2002) Sex differences in cleaning behaviour and diet of a Caribbean cleaning goby. Journal of the Marine Biological Association of the United Kingdom 82, 1-12.

Whiteman E.A., Côté I.M. and Reynolds J.D. (2002) Do cleaning stations affect the distribution of territorial fishes? Coral Reefs 21, 245-251.

Wicksten M.K. (1998) Behaviour of cleaners and their clients fish Bonaire, Netherlands Antilles. Journal of Natural History 32, 13-30.

Wirtz P. (2003) New records of marine invertebrates from São Tomé Island. Journal of the Marine Biological Association of the United Kingdom 83, 735-736.

Wirtz P. (2004) Four amphi-Atlantic shrimps new for São Tomé and Príncipe (eastern central Atlantic). Arquipélago: Life and Marine Sciences 21, 83-85.

Wirtz P., Ferreira C.E.L., Floeter S.R., Fricke R., Gasparini J.L., Iwamoto T., Rocha L.A., Sampaio C.L.S. and Schliewen U. (2007) Coastal fishes of São Tomé and Príncipe islands, Gulf of Guinea (Eastern Atlantic Ocean): an update. Zootaxa 1533, 1-48.

and

Zander D. and Sötje I. (2002) Seasonal and geographical differences in cleaner fish activity in the Mediterranean Sea. Helgoland Marine Research 55, 232-241.

\section{Correspondence should be addressed to:}

J.P. Quimbayo

Laboratório de Biogeografia e Macroecologia Marinha

Departamento de Ecologia e Zoologia

Centro de Ciências Biológicas

Universidade Federal de Santa Catarina

Florianópolis, SC 88010-970, Brazil

email: jupaquia@gmail.com 